\title{
Seismic microzonation of soil amplification and liquefaction for Padang City
}

\author{
Adrin Tohari ${ }^{1, *}$ \\ ${ }^{1}$ Research Center for Geotechnology, Indonesian Institute of Sciences, Bandung, Indonesia
}

\begin{abstract}
The magnitude 7.6 MW earthquake that occurred on 30 September 2009 in West Sumatera caused significant damages to buildings in the city of Padang related to the phenomenon of amplification and liquefaction. This paper presents the results of the assessment and mapping of amplification and liquefaction, carried out in the coastal area of Padang City. Mapping of soil amplification was carried out in 250 locations using the HVSR microtremor method. Meanwhile, evaluation of the potential for liquefaction was carried out in 95 locations using a cone penetration test-based method. Based on the analysis, Padang City has five seismic susceptibility zonations. Coastal areas, including the sub-districts of Koto Tangah, North Padang, West Padang, and South Padang, are located in high to very high susceptibility to soil amplification and liquefaction. These results are in agreement with the phenomenon of building damage due to amplification and liquefaction during the 2009 earthquake.
\end{abstract}

\section{Introduction}

Large earthquakes can trigger not only tsunamis but also liquefaction and ground shaking in coastal cities and consequently cause damage to buildings and infrastructures built on soft soil layers even though they are far from the source of the earthquakes. The soil layers will amplify the earthquake shakings. This condition can occur very extreme in areas where deep sedimentary basins exist. Changes in material stiffness between bedrocks and soft soil layers can cause amplification of earthquake shakings, as observed during the 1995 Michoacan earthquake in Mexico City [1,2].

Large earthquakes can also trigger soil liquefaction, which can cause significant damage to buildings built on

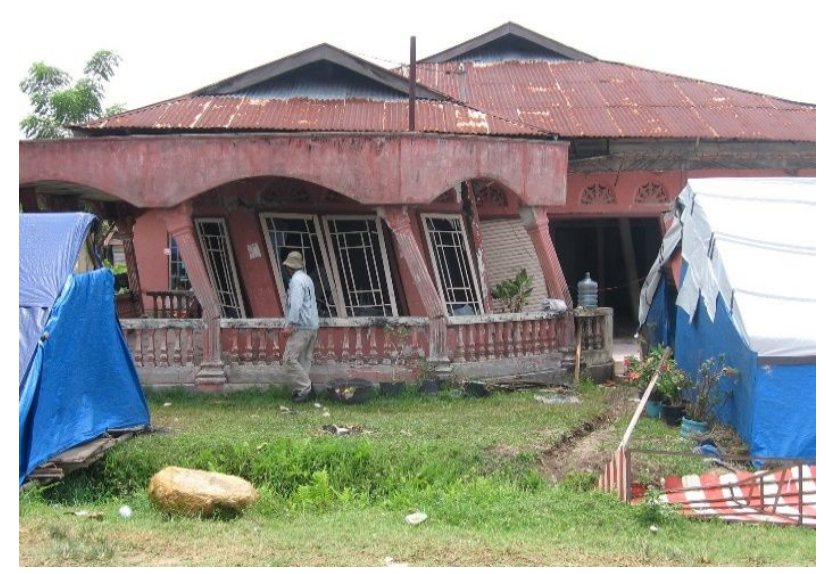

loose, water-saturated layers of sand. Damage caused by liquefaction is generally associated with soil deformation such as lateral spreading, ground oscillation, ground settlement, and loss of soil bearing capacity. Damage losses due to liquefactions can reach more than ten billion dollars. For example, the liquefaction disaster at the 1995 Kobe earthquake resulted in more than 11.8 billion dollars in damage to port and dock facilities [3].

Padang City is one of the coastal cities on the island of Sumatera, which is prone to earthquakes from tectonic activity in the subduction zone. The magnitude 7.6 earthquake (MMI VII-VIII) that struck Padang City on 30 September 2009 caused 320 deaths and significant damage to homes, government buildings, and infrastructure in several locations in the city (Figure 1).

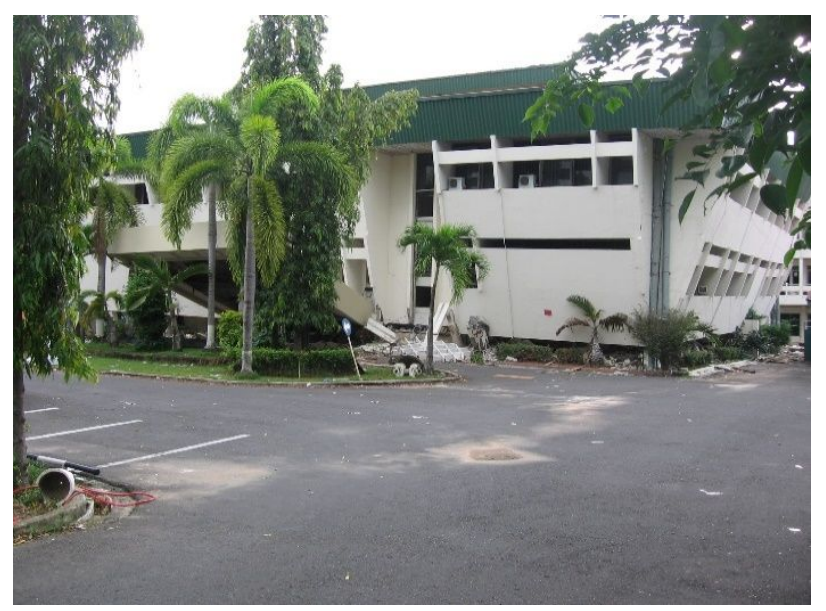

Fig. 1. Damage to houses and government buildings due to the ground amplification during the 30 September 2009 earthquake [4].

\footnotetext{
* Corresponding author: $\underline{\text { adrin.tohari@gmail.com }}$
} 

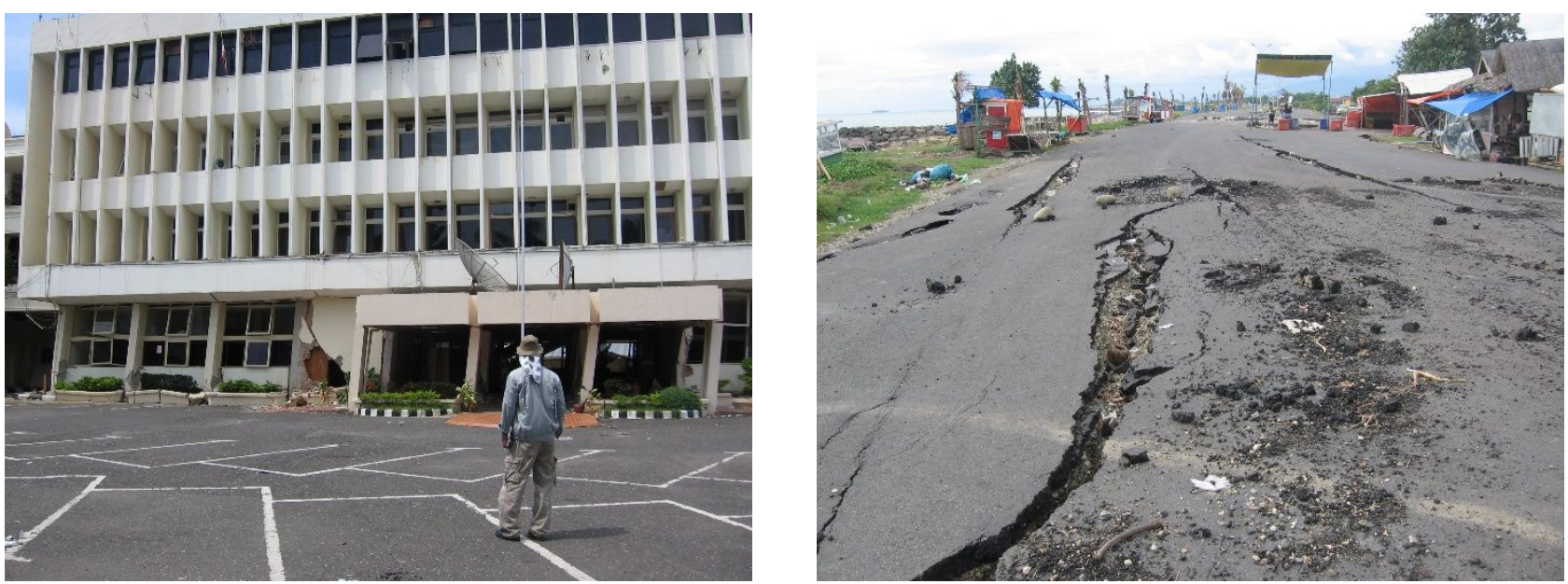

Fig. 2. Damage to government buildings and an embankment road due to liquefaction induced by the 30 September 2009 earthquake [4].

The collapse of buildings generally occurred in some multi-story buildings due to soft-story failure. However, the damaged buildings were observed to concentrate in the southern part of the city. This evidence suggests that subsurface soil conditions in Padang City may have significant control over different site responses to earthquake shakings. According to [4], the coastal area in Padang City consists of layers of soft clay and loose to dense sand layers of varying thickness. As such, the presence of these clay layers is responsible for seismic amplification with different effects from one location to another location.

Building and infrastructure damages in Padang City due to the 2009 earthquake also resulted from soil liquefaction phenomena, such as ground settlement and lateral spreading, followed by sand boiling. For example, the four-story Public Work office building nearby the river bank experienced foundation failure due to ground settlement. Fine sands were also ejected out to the ground surface in the vicinity of the building foundation. The embankment road located along the Padang beach was evident to experience some extensive cracking due to lateral spreading (Figure 2). Some pieces of field evidence also show ground settlement up to $0.5 \mathrm{~m}$ in some residential areas close to the coast [4]. The different degree of damage due to liquefaction is likely to be associated with the existence of loose to medium sand layers with different thickness and depth.

To mitigate the future earthquake hazard associated with soil amplification and the liquefaction, seismic microzonation maps for the Padang City is required to establish an earthquake risk analysis and sustainable development plan. This paper presents the results of the seismic microzonation study based on HVSR microtremor and CPT-based liquefaction methods. The specific objectives of this microzonation study are (1) to obtain the predominant period and amplification factor of soils, (2) to evaluate liquefaction-induced ground settlement, and (3) to develop seismic microzonation maps for Padang City.

\section{Geology and seismo-tectonic setting of Padang City}

\subsection{Geological setting}

Padang City is geologically made up of three different geological units [5]. The oldest rock unit is the Jurassic sedimentary rock, which presents in the hill to the southeast. This Jurassic rock consists of limestone and metamorphic rock and is overlain by Quaternary volcanic rocks in the southern and eastern hilly regions. These volcanic rocks consist of andesitic - basaltic tuff, breccias, and lava. Meanwhile, younger volcanic rocks consist of colluvial material derived from andesitic rocks, such as found on quaternary volcanic slopes in the eastern hills. On the other hand, the Quaternary alluvial deposits, as the youngest rock unit, consist of gravel, sand, silt, and clay layers. These alluvial deposits form an alluvial plain of 10 $\mathrm{km}$ wide in the SW-NE direction and $20 \mathrm{~km}$ long in the NW-SE direction.

\subsection{Seismo-tectonic setting}

Padang City is situated $250 \mathrm{~km}$ east of the Sumatera subduction zone, which is the result of large-scale plate convergence. The Indo-Australian plate is obliquely subducting beneath the Sumatera-Eurasian plate, with an averaged convergence rate of 50-70 mm/year [6-7]. This oblique convergence between the Australian/Indian and Eurasian plate consists of two components, namely the dip-slip component, and the strike-slip component, each of which is accommodated by the subduction interface and the Sumatera fault zone, respectively [8-9].

Several large earthquakes have occurred in the Sumatera subduction zone, one of which occurred in 2009 with a magnitude of $7.6(\mathrm{Mw})$. The epicenter was located offshore about $60 \mathrm{~km}$ northwest of the city, at a depth of about $80 \mathrm{~km}$ on the oceanic slab of the Australian plate. According to the ground motion recorded by the geophysical station PDSI located at the hills of Limau Manis, the earthquake generated a peak ground 
acceleration of $0.3 \mathrm{~g}$. Because the location of the center of Padang City is on thicker soft soil, the ground motion is likely to have been stronger than that recorded at the hills [10].

Meanwhile, the Sumatera fault zone of $1900 \mathrm{~km}$ is divided into 20 segments with a movement rate of 10 to $26 \mathrm{~mm} /$ year and increasing to the northwest [11]. These fault segments are separated by more than a dozen discontinuities, ranging in width of 4 to $12 \mathrm{~km}$, and most of which are dilatational step-overs [9]. Since 1890, around 21 major earthquakes have occurred along this fault zone. Several earthquakes have occurred at some segments located in the West Sumatera region, such as in the Sianok segment in $1926(\mathrm{Ms} \sim 7)$, and the Sumani segment in $1926(\mathrm{Ms} \sim 7), 1943$ (Ms 7.6) and 2007 (Mw 6.4 and 6.3). According to [12], the 2007 Sumani earthquake produced an estimated PGA of 0.06 to $0.08 \mathrm{~g}$ in the Padang city region.

\section{Methodology}

\subsection{Analysis of amplification factor}

Microtremor observations were conducted using a single station microtremor device, GEODAS (Geophysical Data Acquisition System), made by Butan Service Co. (Japan). The microtremor device consists of three velocity-meter sensors and a global positioning system (GPS). The sensors measure three components of vibration, i.e., two horizontal components in N-S and W-E directions and one vertical component in the up-down direction. The available response frequency the sensor ranges from 0.1 to $20 \mathrm{~Hz}$. The sampling frequency was at $100 \mathrm{~Hz}$. The recording length for each observation was 660 seconds. Microtremor observations were carried out during the daylight on the original ground surface, taking into account the site conditions (far from the traffic, and the depth of the groundwater $>2 \mathrm{~m}$. In total, 250 microtremor data have been collected over an area of $125 \mathrm{~km}$ from the

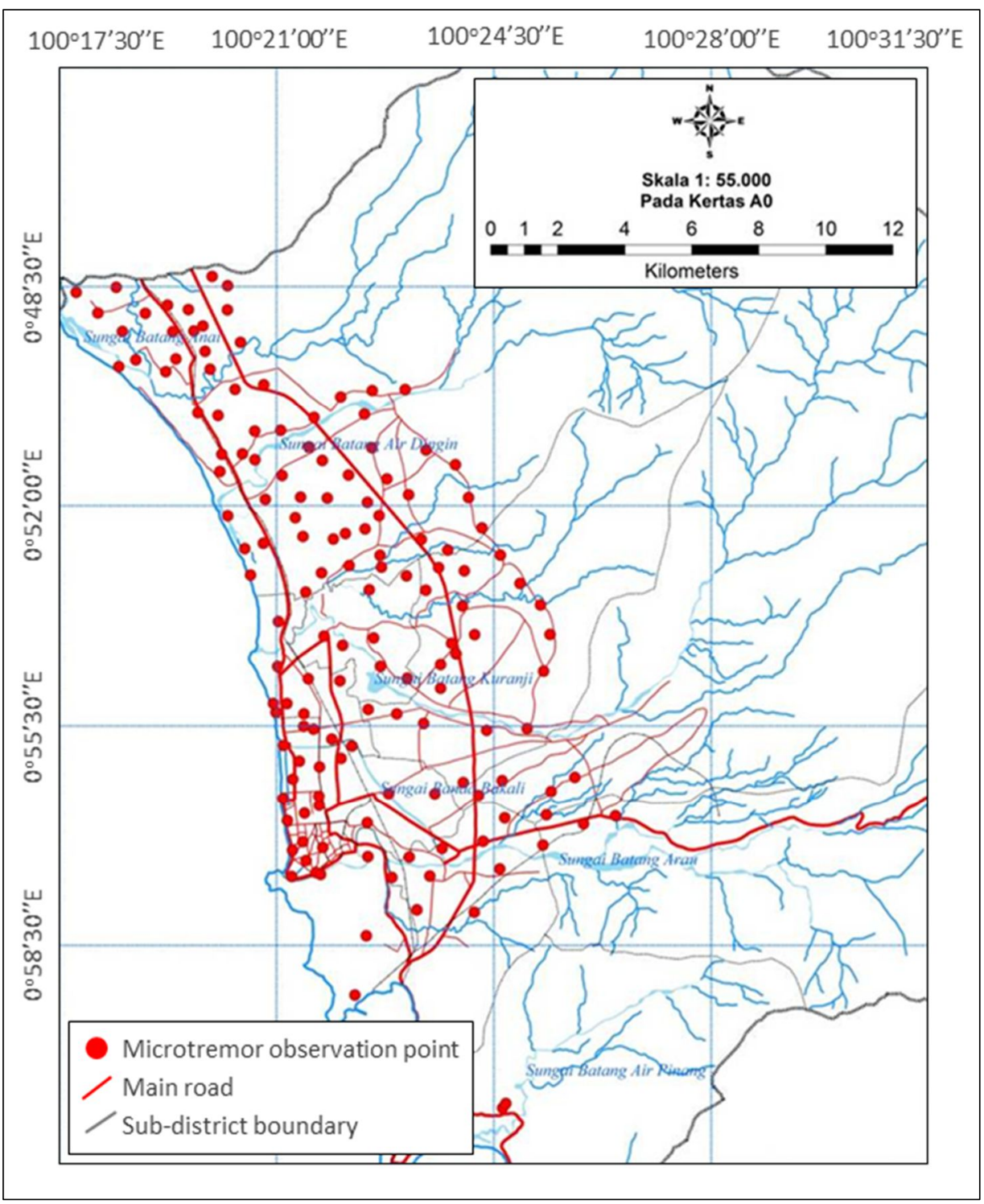

Fig. 3. Locations of microtremor observation. 
coastal to hill areas. The distances between the measurement location ranged from 0.5 to $1 \mathrm{~km}$ (Figure 3 ).

Microtremor data processing was performed using Geonet software. Firstly, the recorded time-series data for each location were divided into 33 data segments, each with a duration of 20 seconds. Then, 20 data segments selected from the 33 data segments were used in the calculation to obtain Fourier spectra using the Fast Fourier Transform (FFT) algorithm. The Fourier amplitude ratio of two horizontal Fourier spectra and one vertical Fourier spectra were obtained based on the following equation:

$$
r(f)=\frac{\sqrt{F_{N S}(f)+F_{E W}(f)}}{F_{U D}(f)}
$$

, where $r(f)$ is the horizontal to vertical spectrum ratio $(\mathrm{H} / \mathrm{V})$, and $F_{N S}, F_{E W}$, and $F_{U D}$ are Fourier amplitude spectra in N-S, E-W, and the up-down directions, respectively. Using the $\mathrm{H} / \mathrm{V}$ spectra for 20 data segments, the average spectra were obtained to determine the spectral ratio curve $(\mathrm{H} / \mathrm{V})$ spectrum for each location. The appearance of a peak on the $\mathrm{H} / \mathrm{V}$ spectrum indicated the distinct difference in impedance between the soil layer and bedrock and is used to identify the predominant period of the soil. Finally, the corresponding peak H/V spectra for the locations of the heavily damaged building were used to develop an amplification susceptibility zonation, as shown in Table 1.

Table 1. Seismic susceptibility zonation based on soil amplification factor [13].

\begin{tabular}{|c|c|}
\hline Amplification factor $(\mathbf{H} / \mathbf{V})$ & Susceptibility zonation \\
\hline $\mathrm{H} / \mathrm{V}<3$ & Very low \\
\hline $3 \leq \mathrm{H} / \mathrm{V}<6$ & Low \\
\hline $6 \leq \mathrm{H} / \mathrm{V}<9$ & Medium \\
\hline $9 \leq \mathrm{H} / \mathrm{V}<12$ & High \\
\hline $\mathrm{H} / \mathrm{V} \geq 12$ & Very high \\
\hline
\end{tabular}

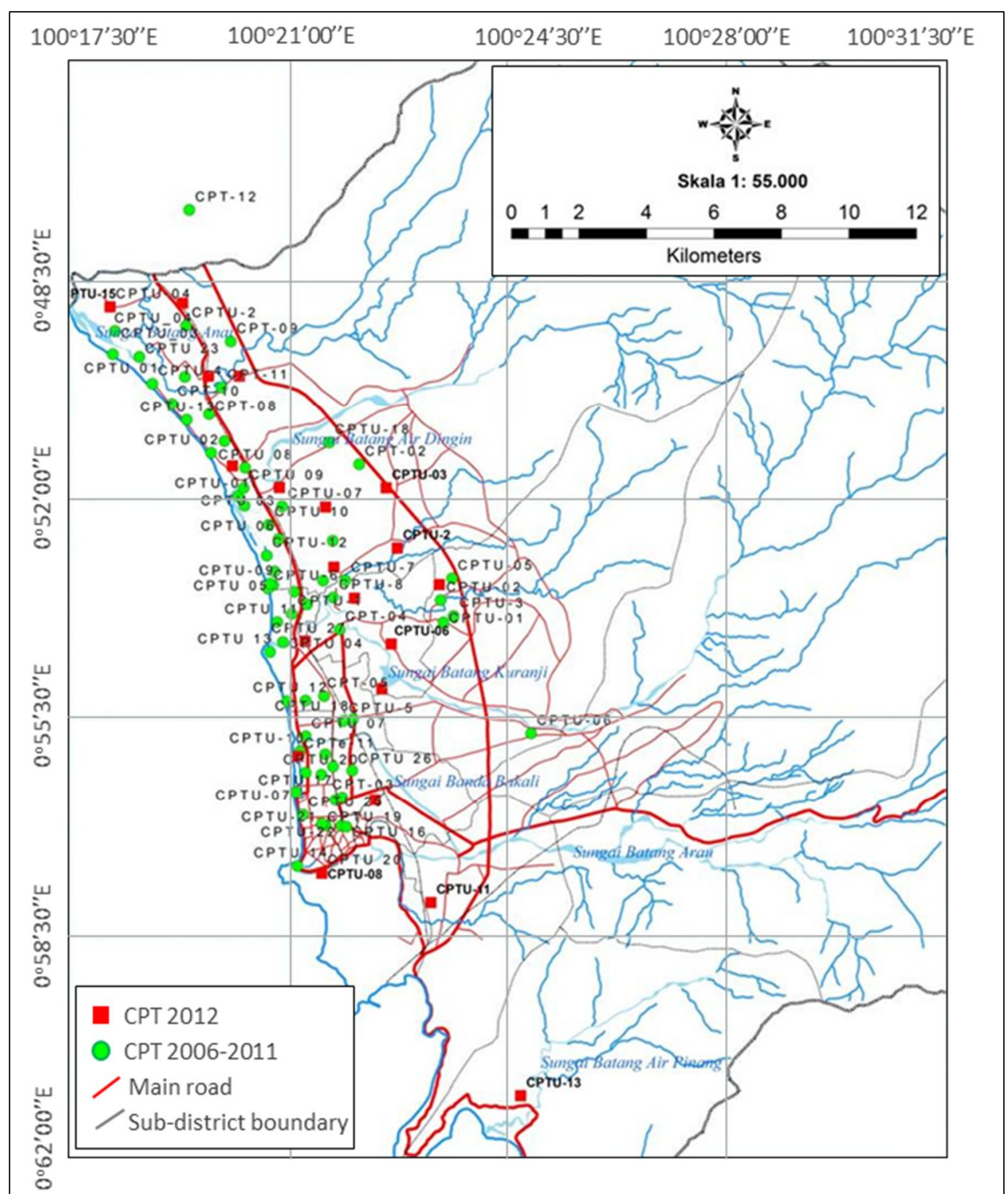

Fig. 4. Locations of cone penetration test (CPT). 


\subsection{Analysis of liquefaction potential}

Figure 4 presents the locations of cone penetration testing $(C P T)$ to obtain a cone tip resistance $\left(q_{c}\right)$ and local resistance $\left(f_{s}\right)$ profile required in evaluating the liquefaction potential. The cone penetration tests were
, where $M S F$ is the magnitude scale factor $=10^{2.24} / M_{w}{ }^{2.56}$, and $M_{w}$ is the magnitude of the earthquake under consideration [17]. In this study, the soil layer is considered not to liquefy when $F S$ is higher than 1.0.

The liquefaction-induced ground settlement at each location was calculated using a procedure described in
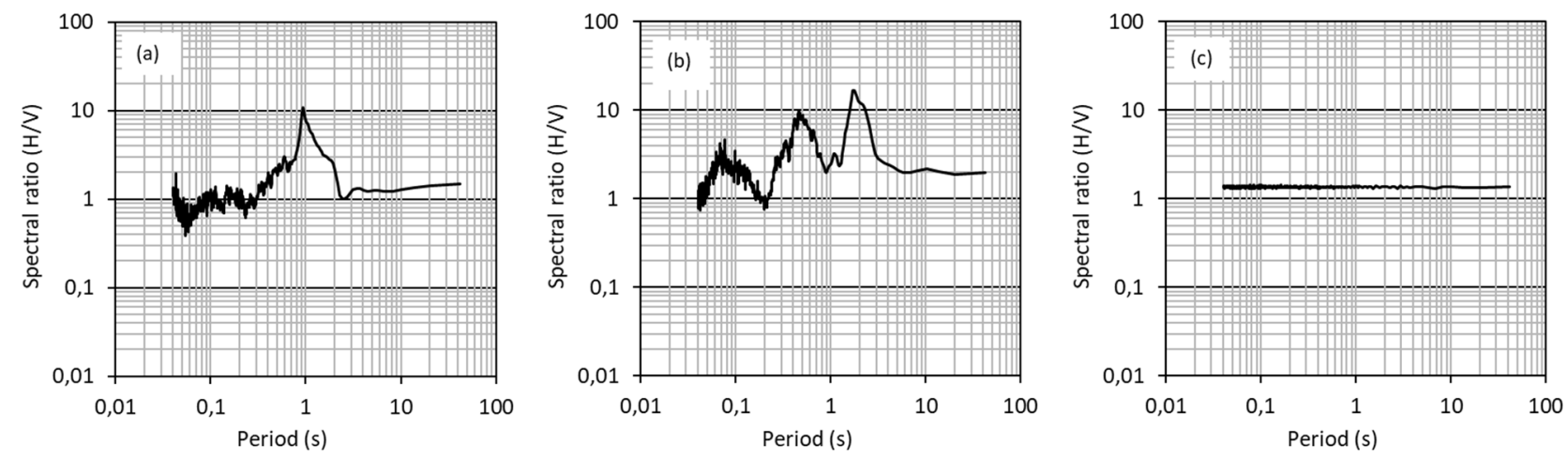

Fig. 5. Types of H/V spectral ratio of soils.

conducted using piezocone at 32 locations and a mechanical cone at 16 locations. Evaluation of liquefaction potential with the cone penetration test method was carried out in 3 (three) stages: (1) calculation of cyclic stress ratio, (2) calculation of cyclic resistance ratio, and (3) calculation of the safety factor against liquefaction.

The cyclic stress ratio (CSR) was calculated using a simplified equation by [14] as follows:

$$
C S R=0.65 \times \frac{a_{\max }}{g} \frac{\sigma_{v 0}}{\sigma_{v 0}^{\prime}} \times r_{d}
$$

, where $\sigma_{\mathrm{v} 0}^{\prime}$ is the effective vertical stress, $a_{\max }$ is the maximum earthquake acceleration at the ground surface, $g$ is the acceleration of gravity, $\sigma_{\mathrm{v} 0}$ is the total vertical stress at depth $\mathrm{z}$, and $r_{d}$ is the shear stress reduction factor that accounts for the dynamic response of the soil profile, according to [14]. [15] suggested the factor 0.65 to account for the difference between the maximum shear stress and the average shear stress induced by an earthquake. Considering that the 30 September 2007 earthquake produced a peak ground acceleration of $0.3 \mathrm{~g}$ at stiff soils, the peak ground acceleration of $0.45 \mathrm{~g}$ was used to analyze liquefaction potential in Padang City.

Meanwhile, the cyclic resistance ratio $(C R R)$ from CPT results was calculated using the equations formulated by [16] as follow:

$$
\begin{aligned}
& C R R_{7.5}= \\
& \left\{\begin{array}{c}
0.833 \times\left[\frac{\left(q_{c 1 N}\right)_{c s}}{1000}\right]+0.05 \text { for }\left(q_{c 1 N}\right)_{c s}<50 \\
93 \times\left[\frac{\left(q_{c 1 N}\right)_{c s}}{1000}\right]^{3}+0.08 \text { for } 50<\left(q_{c 1 N}\right)_{c s}<160
\end{array}\right.
\end{aligned}
$$

, where $C R R_{7.5}$ is the cyclic resistance ratio for magnitude 7.5 earthquake, and $\left(q_{c 1 N}\right)_{c s}$ is the clean-sand cone penetration resistance normalized to approximately $1 \mathrm{~atm}$. Finally, the factor of safety $(F S)$ against liquefaction was calculated using the following equation [14]:

$$
F S=\left(C R R_{7.5} / C S R\right) \times M S F
$$

[18]. Based on the obtained total ground settlement, the liquefaction susceptibility zonation was then developed using the classification given in Table 2.

Table 2. Classification of ground settlement susceptibility zonation (modified from [18]).

\begin{tabular}{|c|c|}
\hline Total ground settlement $(\mathbf{c m})$ & Susceptibility zonation \\
\hline$<5$ & Very low \\
\hline $5-10$ & Low \\
\hline $10-20$ & Medium \\
\hline $20-40$ & High \\
\hline$>40$ & Very high \\
\hline
\end{tabular}

\section{Results and discussions}

\subsection{Spectral ratio analysis}

According to the shape of the spectra, the H/V spectra can be classified into three types (see Figure 5):

- Type A: H/V spectra with one distinct peak [Figure 5 (a)]

- Type B: H/V spectra with two different peaks [Figures 5 (b)]

- Type C: H/V spectra with no peaks [Figure 5 (c)].

The shape of the H/V spectra is affected by the depth of the soil layer. In type A spectral ratio, the influence of alluvial layers at different depths is not distinguishable because the predominant period can represent the effect of either deep soil layers or shallow soil layers [Figure 5 (a)]. Type B spectral ratio is characterized by a low and high predominant period, each associated with a shallow and deep soil layer [Figure 5 (b)]. Meanwhile, the type C spectral ratio represents the influence of the hard soil layer [Figure $5(\mathrm{c})$ ]. 

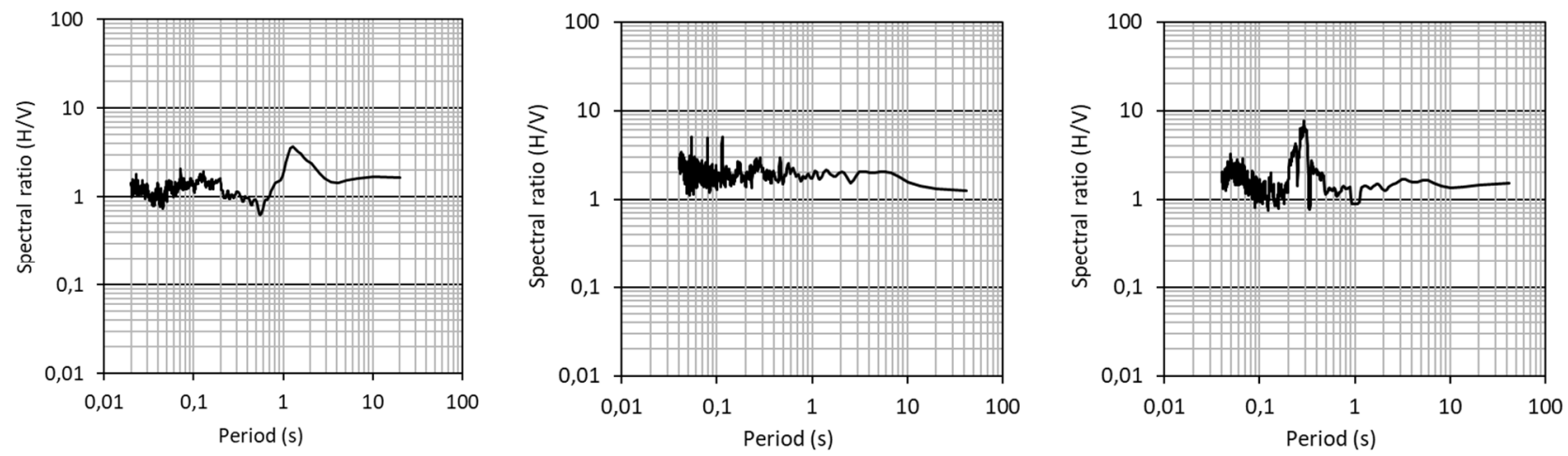

Fig. 6. The spectral ratio H / V based on the type of soil layer: alluvial plains (left), alluvial fan (middle) and volcanic hill (right).

Besides the depth of the soil layer, types of the soil layer also control the shape of the H/V spectra. Figure 6 presents a comparison of spectral ratio curves for the alluvial deposit, alluvial fan deposit, and volcanic soil. The spectral ratio of the alluvial deposit has a more distinct and higher peak than that of the alluvial fan and volcanic soils. The alluvial deposit has a higher predominant period than the alluvial fan and volcanic deposits. Meanwhile, the alluvial fan deposit tends to show a rather flat spectral response with no peak so that the value of the predominant period and the amplification factor at many locations cannot be determined. In contrast, the $\mathrm{H} / \mathrm{V}$ spectral ratio of volcanic deposits tends to have several peaks with a predominant period value of less than 1 second.

\subsection{Liquefaction potential}

Figures 7 and 8 show the results of CPT-based liquefaction potential analysis based on the CPT data and thickness of the liquefiable soil layers vary from one location to another. This evidence suggests that the subsurface geological condition controls the liquefaction hazard in Padang City.

All the graphs in Figures 7 and 8 also indicate that liquefaction generally occurs in soil layers up to a depth of $15 \mathrm{~m}$ with the tip resistance $\left(q_{c}\right)$ and sleeve resistance $\left(f_{s}\right)$ values being less than $10 \mathrm{MPa}$ and $60 \mathrm{kPa}$, respectively. However, soil liquefaction will not occur, in particular, in soil layers having the $q_{c}$ and $f_{s}$ values of less than $2 \mathrm{MPa}$ and ten $\mathrm{kPa}$, respectively. According to the soil behavior index [19], these values represent the sensitive fine-grained to clay-like soils.

Based on the calculation using the procedure given by [17], the liquefaction induces a vertical ground settlement of up to $40 \mathrm{~cm}$. Hence, the coastal area can be classified as a high susceptible zone to the ground settlement (see Table 2). The examination of Figures 7 and 8 indicates the ground settlement varies from one location to another due to the different soil type and density at each location. In
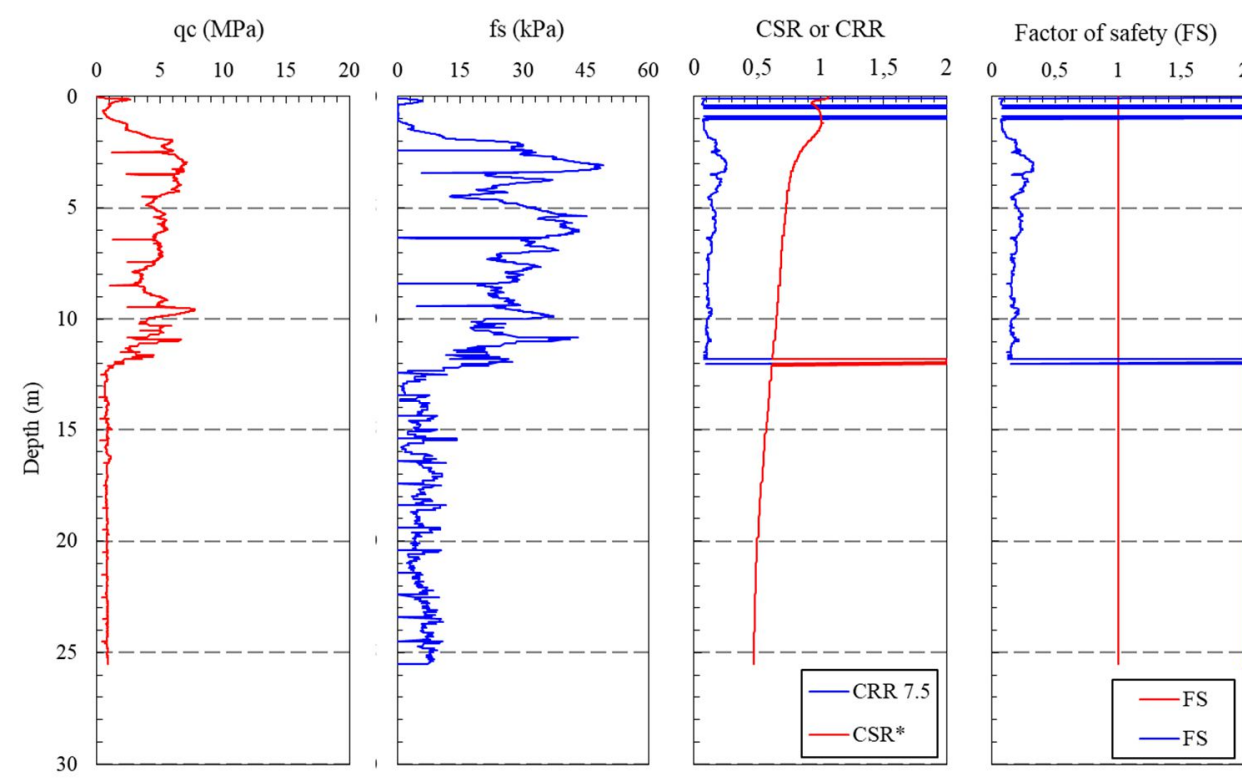

Total settlement $(\mathrm{cm})$
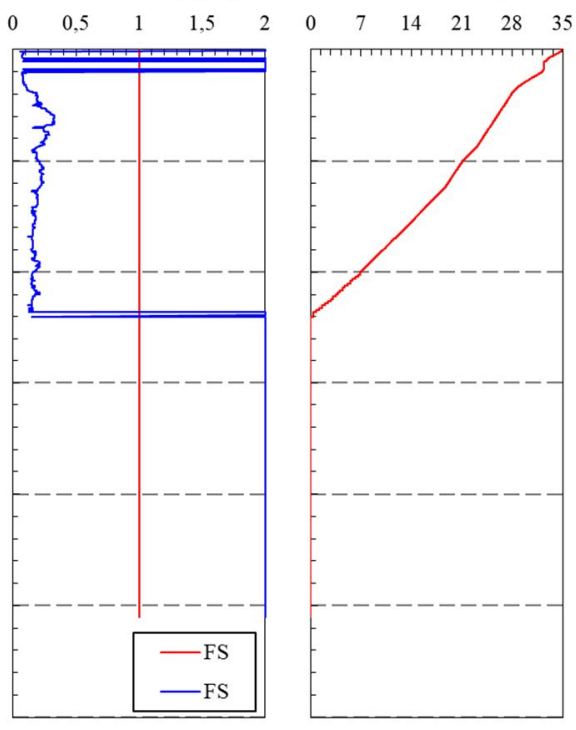

Fig. 7. Results of cone penetration test (CPT) and liquefaction potential for CPTU-01 (Pasir Jambak).

obtained in the 2009 liquefaction sites near the coast. The liquefiable soil layers are indicated by the values of factor of safety lower than 1.0. These figures show that the depth other words, the specific geological condition will control the ground settlement. 


\subsection{Microzonation of soil amplification factor}

Figure 9 shows the results of microzonation based on the soil amplification factor $(\mathrm{H} / \mathrm{V})$ values. Examination of
Koto Tangah, Nanggalo, and Padang Utara sub-districts. While the southern parts of Padang Utara, Padang Timur, and Padang Barat, as well as the northern part of Padang
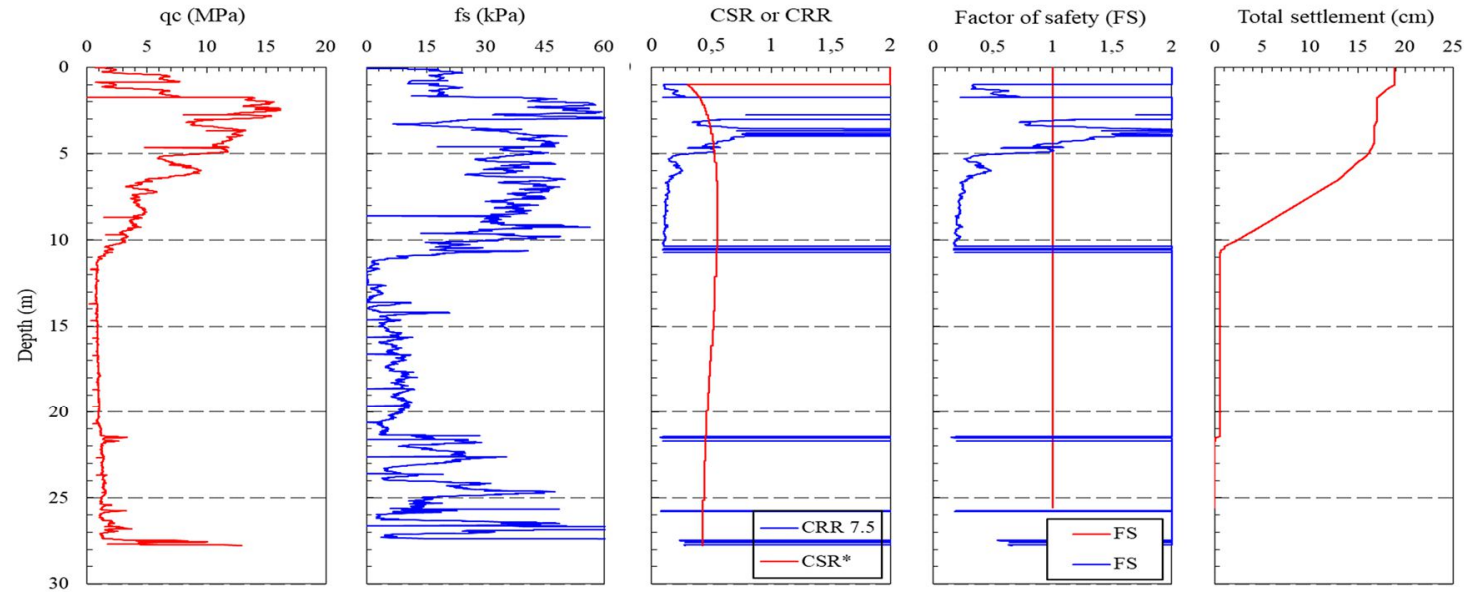

Fig. 8. Results of cone penetration test (CPT) and lic efaction potential for CPTU 11 (UNP football yard).

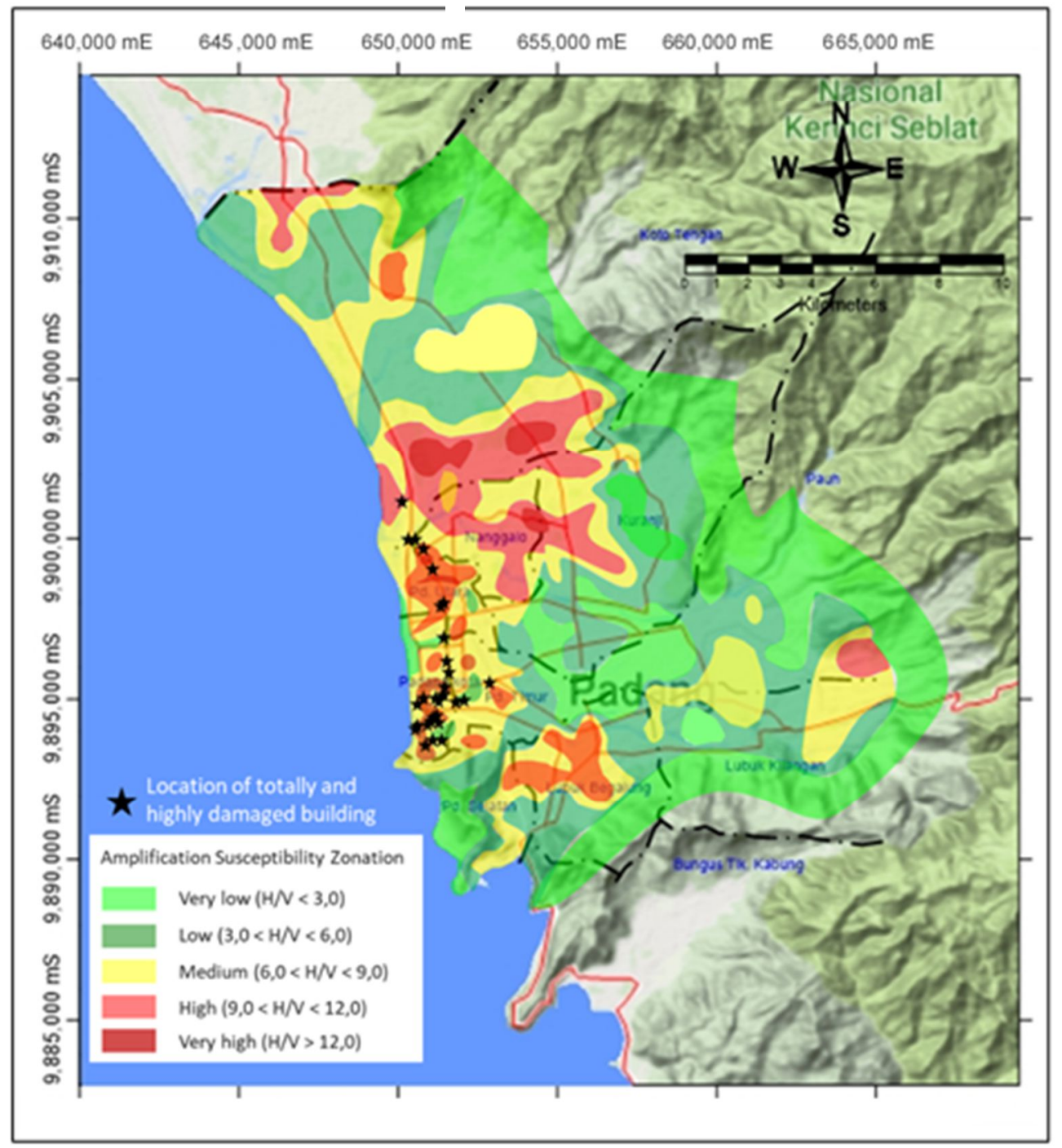

Fig. 9. The seismic microzonation map based on soil amplification factor (modified from [13]).

this figure, most of the coastal areas are classified into moderate to high susceptibility zones, especially areas in
Selatan sub-districts, are classified into high to very high susceptibility zones. 
According to Figure 9, Padang City can be divided into five susceptibility zones, as described in detail as follows:

○ Very low amplification zone includes hilly areas in Koto Tangah, Kuranji, Pauh, Padang Selatan, Lubuk Kilangan, and Lubuk Begalung.

- Low amplification zone includes the areas in Pasir Nan Tigo, Bungo Pasang, Dadok Tunggul Hitam, Baitipuh Panjang, Lolong Belanti, Padang Arai, Kuranji, and Limau Manis.

- Medium amplification zone covers the areas in Gunung Sariek, Jati, Olo, Sungai Sapieh, Lubuk Buaya, Tabing, Air Tawar Barat, and Padang Sarai.

- High amplification zone includes the areas in Baitipuh Panjang, Flamboyan, Parak Laweh, Andalas, Air Tawar Timur, Berok Nipah, and Kampung Jao.

- Very high amplification zone includes the areas in Belakang Tangsi, Sawahan, Ulak Karang Utara, and Kampung Lapai.

The microzonation map also shows that the locations of all high-rise buildings that suffered severe damages in agreement with the phenomena of building damages observed during the 2009 earthquake.

According to a study conducted using MASW in Padang City [20], the soil layer up $30 \mathrm{~m}$ thick in the coastal area of Padang City is generally classified as soft soil (SE to SD). Referring to [21], these site classes will produce amplification factors of 2.6 and 2.4 for $0.3<$ PGA $<0.4 \mathrm{~g}$. Meanwhile, the soil layer at hilly areas will have smaller amplification factors. Thus, this study indicates the amplification factors of soil layers in Padang City are very site-specific, as does the microtremor measurement reported in this paper.

\subsection{Microzonation of soil liquefaction}

Based on the calculated ground settlement and the classification of liquefaction susceptibility shown in Table 2, a liquefaction susceptibility map for Padang City was developed (Figure 10). As seen in this figure, Padang City is divided into five zones from very low to very high liquefaction susceptibility. The area of very high

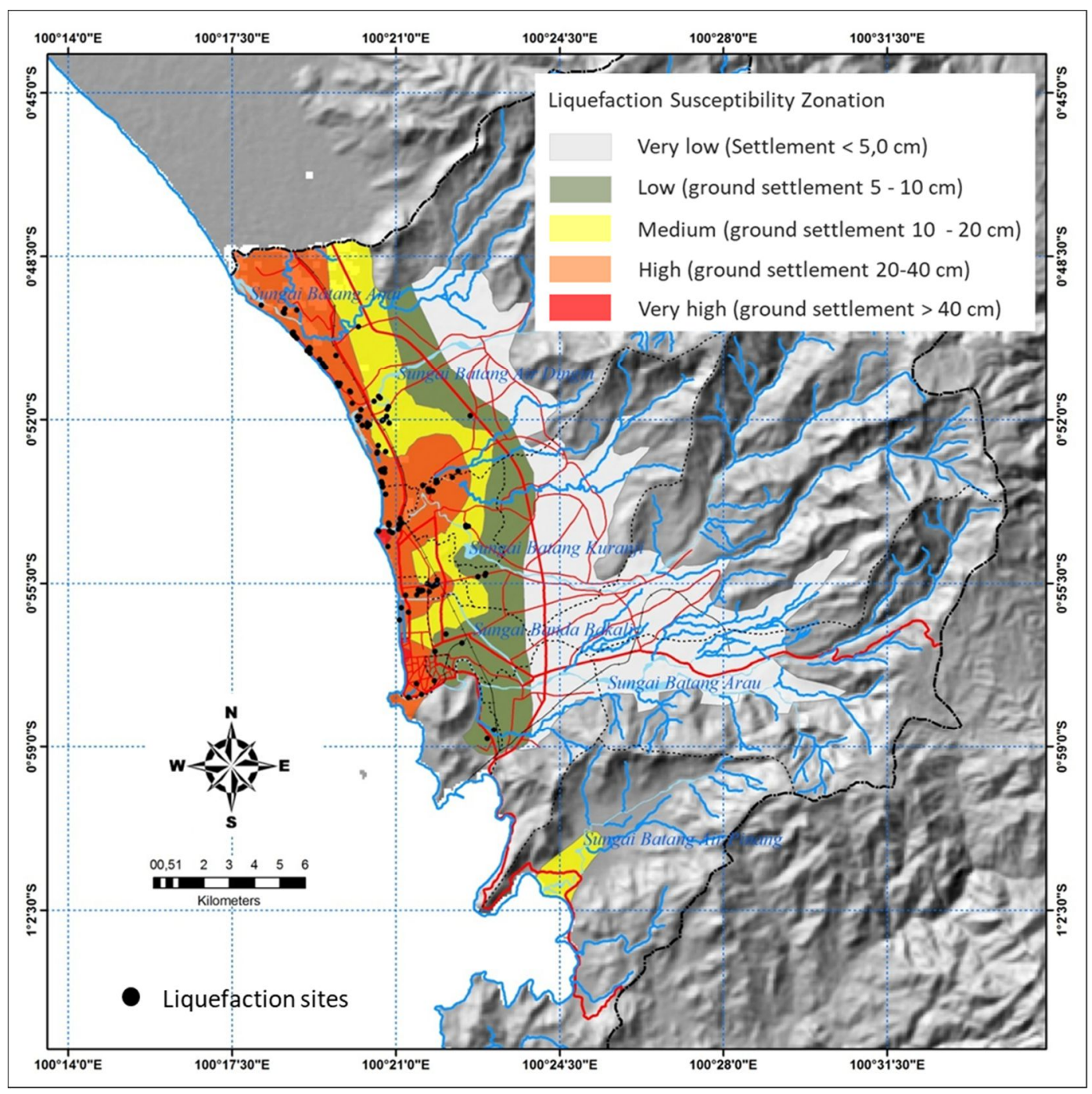

Fig. 10. The liquefaction susceptibility microzonation map based on total ground settlement.

the 2009 earthquake were in high to very high amplification zone. Therefore, the microzonation map developed in this study shows, in general, a good susceptibility zone concentrates along the shoreline. The extent of the area in the north-western part is larger than the south-eastern part of the city. The area of the very high 
vulnerability zone also decreases north-eastward from the coastline.

According to Figure 10, liquefaction susceptibility zonation for Padang City, based on the ground settlement, can be described as follows:

○ Very low susceptibility zone covers the hill foot regions in Koto Tangah, Pauh, Kuranji, Lubuk Kilangan, and Lubuk Begalung.

- Low susceptibility zone covers the areas ini Bungo Pasang, Air Pacah, Sungai Sapieh, Tabing Banda Gadang, Sawahan, Parak Laweh, and Koto Panjang Ikur Koto.

- Moderate susceptibility zone includes the areas in Air Tawar Barat, Purus, Dadok Tunggul Hitam. Lubuk Buaya bagian timur, Air Tawar Timur, Batang Kabung Ganting, and Bungus Teluk Kabung.

- High susceptibility zone includes the regions in Pasir Nan Tigo, Lubuk Buaya bagian barat, Padang Sarai, Parupuk Tabing bagian barat, Kampung Jambak, Air Tawar Barat, Ulak Karang Selatan, Kurao Pagang, Kampung Jao, Flamboyan Baru, Batang Arau, and Berok Nipah.

- Very high susceptibility zone covers the areas in Pasir Nan Tigo, Lubuk Buaya, Bungo Pasang, Kp. Olo, and Ulak Karang Utara.

Figure 10 also shows the plot of all sites of the observable liquefaction due to the 2009 earthquake, i.e., the ground settlement, sand boiling, and lateral spreading. As indicated in Figure 10, there is a good agreement between predicted zones and the liquefaction sites observed after the earthquake. In particular, Koto Tangah, Padang Utara, Padang Timur, and Padang Selatan subdistricts, where ground settlements occurred, are in high to very high liquefaction susceptibility zones.

\section{Conclusions}

Based on the available microtremor observation and cone penetration test data, the seismic microzonation for Padang City was developed and compared to the 2009 earthquake-affected areas. The main conclusions are as follow:

a. The coastal area, which is composed of alluvial material, tends to have a higher predominant period and amplification factor than the hilly slope area made up of an alluvial fan and volcanic materials.

b. Based on the amplification factors, Padang City can be divided into five amplification susceptibility zones from very low to very high susceptibility zones. According to the microzonation map, the locations of severely damaged buildings in the 2009 earthquake are in high to very high seismic susceptibility zones.

c. The CPT-based liquefaction potential analysis shows that the liquefaction will induce ground settlement with various magnitude.

d. Based on the variation of ground settlement, Padang City can be classified into five liquefaction susceptibility zones from very low to very high susceptibility zones. The coastal areas, including Koto Tangah, Padang Utara, Padang Barat, and Padang Selatan sub-districts, are located in high to very high susceptibility to liquefaction-induced ground settlement.

e. The liquefaction susceptibility map shows a good agreement with the field observations conducted after the 2009 earthquake event. The locations where the ground settlements occurred are obviously in high to very high liquefaction susceptibility zones.

The author would like to thank the Research Centre for Geotechnology-Indonesian Institute of Sciences (LIPI) for the support to conduct a liquefaction potential mapping in 2006 and 2008 as well as field observations of liquefaction phenomena in Padang City few days after the 2019 earthquake. The funding received from Japan Science and Technology (JST) made possible field liquefaction investigations in 2010 and 2011. The microtremor equipment used in this study was provided by the Japan International Cooperation Agency (JICA) in 2010.

\section{References}

1. J. Lermo, F.J Chavez-Garcia, Bull. Seism. Soc. Am. 83, 1574-1594 (1993).

2. H.B Seed, M.P. Romo, J.I. Sun, A. Jaime, J. Lysmer, Earthq. Spec. 4, 687-729 (1988).

3. EQE International, The January 17, 1995, Kobe Earthquake: An EQE Summary Report. San Francisco: EQE, 1995.

4. A. Tohari, K. Sugianti, E. Soebowo, J. Ris. Geol. Tamb. 21(1), 7-18 (2011).

5. D. Kastowo, L.W. Gerhard, Geologic map of the Padang Quadrangle, Sumatera: Geological Survey of Indonesia, Ministry of Mines 4/VIII (1973).

6. L. Prawirodirdjo, Y. Block, J.F. Genrich, S.S.O. Puntodewo, J. Rais, C. Subarya, S. Sutisna, J. Geophys. Res. 105, 28,343-28,363 (2000).

7. D.H. Natawidjaja, K. Sieh, S.N. Ward, H. Cheng, R.L Edwards, J. Galetzka, B.W. Suwargadi, J. Geophys. Res. 109, B04306 (2004).

8. R. McCaffrey, Geol. 19, 881- 884 (1991).

9. K. Sieh, D.H Natawidjaja, J. Geophy. Res. 105(B12), 28,295-28,326 (2000).

10. EERI, Special Earthquake Report - December (2009).

11. D.H. Natawidjaja, W. Triyoso, J. Earthq. Tsun. 1(1), 21-47 (2007).

12. USGS, M 6.4 - Southern Sumatera, Indonesia: Shake $\operatorname{Map}$ (2007).

13. A. Tohari, D. D. Wardhana, J. Ris. Geol. Tamb. 28(2), 205-220 (2018).

14. H.B Seed, I.M Idriss, J. Soil Mech. Found. Div. 97(SM9), 1249 - 1273 (1971).

15. S.S.C. Liao, R.V. Whitman, J. Geotech. Engrg. 112(3), 373-377 (1986).

16. P.K Robertson, C.E Wride, Can. Geotech. J. 35(3), 442-459 (1998).

17. T.L Youd, I.M Idriss, R.D Andrus, I. Arango, G. Castro, J.T Christian, E. Dorbry, W.D. L Finn, L.F Harder Jr, M.F Hyness, K. Ishihara, J. Koester, S.S.C 
Liao, W.F. Marcuson, R. Martin, J.K Mitchell, Y. Moriwaki, M.S Power, P.K Robertson, R.B. Seed, K.H. Stokoe, J. Geotech. Geoenviron. Engrg. 124(10), 817-833 (2001).

18. K. Ishihara, M. Yoshimine, Soils Found. 32(1), 173188 (1992).

19. P.K. Robertson, Can. Geotech. J. 27(1), 151-158 (1990).
20. I.W. Sengara, G. Handayani, D. Apriadi, K.M. Abuhuroyroh, H.G. Putra, Peak Ground Acceleration Estimate based on MASW Survey and Existing Geotechnical Data for City of Padang and Pariaman, Final Report, ITB, Bandung (2010).

21. SNI 1726:2012, Earthquake Resistant Planning Procedures for Structures of Building and NonBuilding. Jakarta: Badan Standarisasi Nasional, (2012) - in Indonesian. 